\title{
Retraction Note to: Molecular Cloning, Sequence Characterization, and Tissue Expression Analysis of Hi-Line Brown Chicken Akirin2
}

\author{
Chaolai Man $\cdot$ Xiang $\mathrm{Li} \cdot$ Jongeun Lee
}

Published online: 10 February 2012

(C) Springer Science+Business Media, LLC 2012

\section{Retraction Note: Protein J}

(2011) 30:471-479

DOI 10.1007/s10930-011-9352-y

This paper has been retracted. The editor-in-chief has determined that the paper is very similar to a paper that was previously published by the same authors. In addition, extensive sections of text were copied from material that was previously published by others.

The online version of the original article can be found under doi:10.1007/s10930-011-9352-y.

C. Man $(\bowtie) \cdot$ X. Li $\cdot$ J. Lee

College of Life Science and Technology, Harbin Normal

University, No. 1 South of Shida RD Limin Development Zone,

Harbin 150025, Heilongjiang, People's Republic of China

e-mail: manchaolai@126.com 